\title{
Can Mössbauer methods of classifying ordinary chondrites help to identify non-representative samples of these meteorites?
}

\author{
Martyna Jakubowska ${ }^{1}$ (D) Jolanta Gałązka-Friedman ${ }^{1}$ (D) Marek Woźniak $^{2}$ (D) \\ Patrycja Bogusz ${ }^{1}$ (D) . Łukasz Karwowski ${ }^{3}$ (D) . Przemysław Duda ${ }^{1}$ (i)
}

Accepted: 19 November 2021 / Published online: 4 December 2021

(C) The Author(s) 2021

\begin{abstract}
Mössbauer spectra of nonweathered ordinary chondrites consist of four main mineral phases: olivines, pyroxenes, metallic phase and troilite. These minerals represent more than $95 \%$ of the whole mass of an ordinary chondrite. Distribution of these mineral phases in micro-scale is not homogeneous. Nevertheless, preparation of representative sample of ordinary chondrite for Mössbauer measurements is possible. To do that a part of $1 \mathrm{~g}$ nonweathered material, selected from inside of meteorite without any specific intention is needed. The Warsaw group has been working on investigation of meteorites for 25 years and has analysed about 150 Mössbauer spectra of various meteorites. Among them we found 15 spectra, which could be suspected of being non-representative. These spectra were obtained from Baszkówka, Amber, Bjurböle, Krasnoi-Ugol and Chelyabinsk meteorites. The analysis of how the samples of meteorites were selected for investigation, has shown that the non-representativeness of samples may be due to: intentional choice of sample, preparation of sample from a too small part of material or the use of non-credible source of meteoritic samples. For confirmation of these assumptions, we used a new method of classification of ordinary chondrites - the $4 \mathrm{M}$ method. It turned out that this method is a very useful tool for investigation of non-representative samples of equilibrated ordinary chondrites.
\end{abstract}

Keywords Classification of ordinary chondrites $\cdot 4 \mathrm{M}$ method $\cdot$ Non-representative samples $\cdot$ Mahalanobis distances $\cdot$ Baszkówka $\cdot$ Chelyabinsk $\cdot$ Bjurböle

This article is part of the Topical Collection on Proceedings of the International Conference on the Applications of the Mössbauer Effect (ICAME 2021), Brasov, Romania, 5-10 September 2021 Edited by Victor Kuncser

Martyna Jakubowska

martyna.jakubowska@pw.edu.pl

1 Faculty of Physics, Warsaw University of Technology, Koszykowa 75, 00-662 Warsaw, Poland

2 Faculty of Biology, University of Warsaw, Miecznikowa 1, 02-096 Warsaw, Poland

3 Faculty of Natural Sciences, University of Silesia, Sosnowiec, Poland 


\section{Introduction}

Ordinary chondrites are a class of stony meteorites. They are the most numerous group of meteorites falling on Earth. They are divided into types: type $\mathrm{H}$ (high iron), L (low iron), and LL (low iron, low metal). In 1969 Herr and Skerra [1] suggested that the Mössbauer spectroscopy can be a very useful technique for the classification of stony meteorites. The Warsaw group has been using the Mössbauer spectroscopy to classify ordinary chondrites since 2014 [2-8].

A method called 4M was developed, based on a mathematical analysis of the percentages of Mössbauer spectral areas of four mineral phases present in ordinary chondrites [7]. This method uses the Mahalanobis distance and the levels of similarity to the individual types of ordinary chondrites. Present version of $4 \mathrm{M}$ method was elaborated for nonweathered ordinary chondrites $\left(\mathrm{Fe}^{3+} \leq 7 \%\right)$.

When percentages of Mössbauer spectral areas associated with four main mineral phases (olivine, pyroxene, metallic phase, troilite) of the investigated ordinary chondrite are very distant from mean values obtained for 3 clusters (type H, type L, type LL) present in our database, we can suspect that investigated samples are not-representative. To confirm our doubts we have to find causes of discrepancies of the results.

The distribution of the four main mineral phases (olivine, pyroxene, $\mathrm{Fe}, \mathrm{Ni}$ - metallic phase, and troilite) in ordinary chondrites is not homogeneous. Nevertheless, it is not impossible to prepare a representative sample of these meteorites for Mössbauer measurements. These fragments should be selected from the inside part of the meteorite because the outer part of the meteorite, together with the melting crust, is characterized by a slightly different mineral composition. A $1 \mathrm{~g}$ fragment of nonweathered ordinary chondrite, selected without any specific intention, allows us, after powdering and mixing the material, to prepare a representative sample. We prepare samples weighing less than $100 \mathrm{mg}$ for measurements. In the samples which do not fulfil the criterion of thin absorbent, the proportions between percentages of Mössbauer spectral areas are conserved. This is of important significance for the proper functioning of the $4 \mathrm{M}$ method.

The Warsaw Group has been involved in the Mössbauer meteorite research for over 25 years. During this period, we have analysed approximately 150 Mössbauer spectra of various meteorites. These were Mössbauer spectra obtained in our laboratory or in laboratories cooperating with us (Racah Institute of Physics in Jerusalem and Kazimierz Pułaski University of Technology and Humanities in Radom) and spectra published in the literature. Among this material, we observed 15 spectra that could be spectra of non-representative samples.

\section{Material and methods}

Fifteen Mössbauer spectra of samples of ordinary chondrites, which assumed to be non-representative, were analysed.

Twelve Mössbauer spectra data (Baszkówka B1, Baszkówka B2, Baszkówka B3, Baszkówka B4 [4], Mbale W, Mbale E, Mbale K [2], Chelyabinsk No 1, Chelyabinsk No 2, Chelyabinsk No 3, Chelyabinsk No 4, Chelyabinsk No 5 [9]) were taken from 

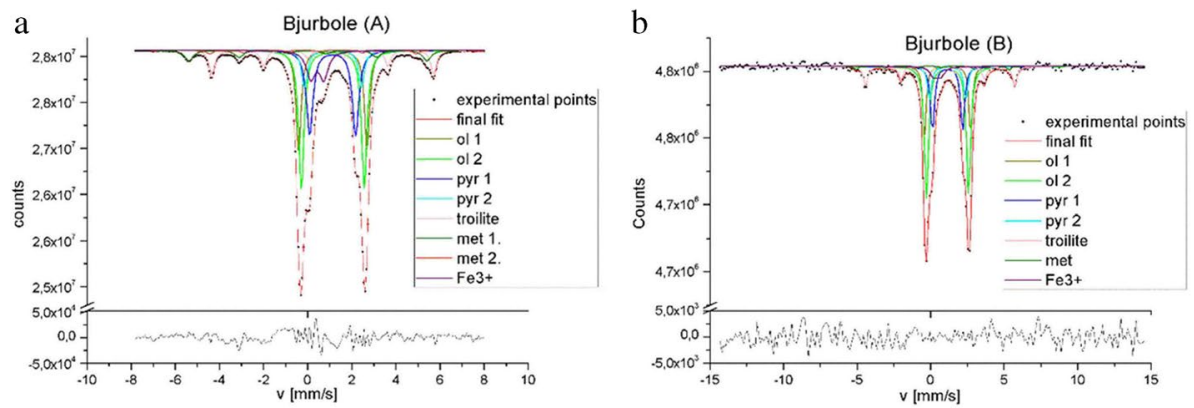

Fig. 1 Mössbauer spectra of two samples of the Bjurböle meteorite

the literature. Three samples (Amber, Bjurböle (A), and Krasnoi-Ugol) were recently investigated in the Warsaw laboratory. We also recently analysed, once again, Bjurböle (B) sample.

In the Warsaw laboratory, Mössbauer spectra were measured at room temperature. The meteorite samples were ground into powder in an agate mortar in the presence of isopropyl alcohol (to stop the oxidation process). For Mössbauer measurements, special holders with samples of meteorites in powdered form were used. A ${ }^{57} \mathrm{Co}$ - in rhodium source was used. Data was collected in 512 channels and then folded to 256 channels (a few million counts/ channel). The fitting procedure was performed using the Recoil [10] program with "Full Static Hamiltonian" analysis. Based on literature [11] and our previous work [12], we can assume approximately equal f-factors for the different iron-containing minerals present in meteorite.

\section{Results}

In Fig. 1 Mössbauer spectra of meteorites Bjurböle (A) and Bjurböle (B) are presented. For two samples of the Bjurböle meteorite the percentages of the spectral area of olivine, pyroxene, troilite, and mineral phase are shown.

In Fig. 2 Mössbauer spectra of meteorites Amber and Krasnoi-Ugol are presented. Spectra were obtained in Warsaw Mössbauer Lab, but samples were delivered in powdered form.

In Table 1 Mössbauer parameters obtained from the best fit to the experimental spectra of the following meteorites: Bjurböle (A), Bjurböle (B), Amber and Krasnoi-Ugol, are presented.

\section{Discussion}

For all samples, the Mahalanobis distances and the level of similarity to three types of ordinary chondrites were calculated. For calculations the script described in 2021 (http:// $4 \mathrm{~m}$-basev1.woreczko.pl/4mmlist.php) was used. Because sample of the meteorite Bjurböle (A) raised our doubts, we decided to examine other samples from this collection. We also analysed samples Amber and Krasnoi-Ugol from the AB collection. These meteorites had 

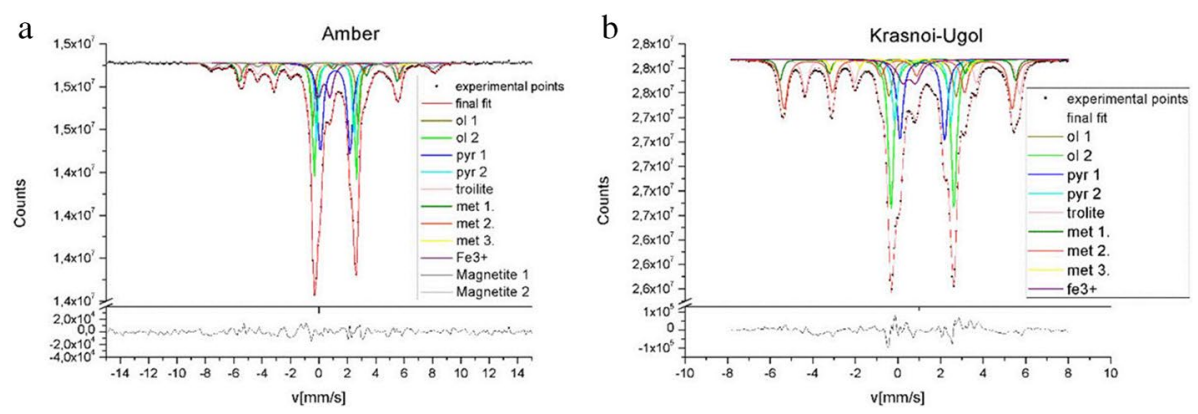

Fig. 2 Mössbauer spectra of samples of the meteorites Amber and Krasnoi-Ugol

a higher degree of weathering (Amber $9 \% \mathrm{Fe}^{3+}$; Bjurböle (A) $8 \% \mathrm{Fe}^{3+}$ ). For samples with the level of ferric iron higher than $7 \%$, we cannot use the $4 \mathrm{M}$ method to classify meteorites, but in this work we use this method only to identify samples that raise doubts as to their representativeness. The results of these samples are carefully analysed later in this work.

The results of these calculations are presented in Table 2 . We analysed total spectral area of olivine $(\mathrm{ol}=\mathrm{ol} 1+\mathrm{ol} 2)$, total spectral area of pyroxene $(\mathrm{pyr}=\mathrm{pyr} 1+$ pyr 2$)$, total spectral area of all metallic phases (met $=$ met $1+$ met $2+$ met 3$)$.

The comparison of the classification results obtained by the $4 \mathrm{M}$ method, showed that for only two samples: Bjurböle (B) and Mbale E, this classification is consistent with the traditional classification based on the determination of the $\mathrm{Fa} / \mathrm{Fs}$ ratio by means of an electron probe.

As we originally assumed, the remaining samples may be unrepresentative. In this work, we will try to find the reasons for this non-representativeness.

\subsection{Baszkówka meteorite}

Our group has been studying meteorites using Mössbauer spectroscopy since 1996 [13]. The analysis of Mössbauer spectra of the Baszkówka meteorite led us to become interested in the problem of non-representative samples. At the beginning of the research of the Baszkówka meteorite, we were mainly interested in the Mössbauer parameters of the troilite $[13,14]$ The people responsible for supplying the samples of the Baszkówka meteorite for research, provided us with such fragments in which the content of troilite was significantly increased. It was intentional but done in good faith. Unfortunately, we were not directly informed about it. In the years 2012-2017, we conducted studies of the Baszkówka meteorite compared with other ordinary chondrites $[2,4,15]$. The results of these studies were unequivocal: percentages of spectral areas in Baszkówka were different than in other ordinary chondrites. The paper published in 2017 [4] shows that the cause was a significant excess of troilite in all the samples of the Baszkówka that we examined. The people who gave us these samples confirmed this conclusion.

\subsection{Mbale meteorite}

Three different samples of the Mbale meteorite were analysed, each of them was measured in a different laboratory: Mbale W - in Warsaw, Mbale E - in Ekaterinburg, and Mbale K 
Table 1 Mössbauer parameters samples of meteorites: Amber, Krasnoi-Ugol, Bjurböle (A) and Bjurböle (B)

\begin{tabular}{|c|c|c|c|c|c|c|c|c|}
\hline Ordinary chondrite & Mineral phase & $\begin{array}{l}\text { Indication } \\
\text { in Fig. } 1 \text { and } \\
\text { Fig. } 2\end{array}$ & $\begin{array}{l}\text { IS } \\
\left(\mathrm{mm} \mathrm{s}^{-1}\right)\end{array}$ & $\begin{array}{l}\text { B } \\
(\mathrm{T})\end{array}$ & $\begin{array}{l}\text { QS } \\
\left(\mathrm{mm} \mathrm{s}^{-1}\right)\end{array}$ & $\begin{array}{l}\Theta \\
\left(^{\circ}\right)\end{array}$ & $\begin{array}{l}\mathrm{W} \\
\left(\mathrm{mm} \mathrm{s}^{-1}\right)\end{array}$ & $\begin{array}{l}\text { A } \\
(\%)\end{array}$ \\
\hline Bjurböle (A) & olivine (site M1) & ol 1 & 1.14 & - & 3.10 & - & 0.14 & 18.6 \\
\hline \multirow[t]{7}{*}{ type L/LL4 } & olivine (site M2) & ol 2 & 1.14 & - & 2.85 & - & 0.15 & 27.0 \\
\hline & pyroxene (site M1) & pyr 1 & 1.15 & - & 2.58 & - & 0.15 & 7.7 \\
\hline & pyroxene (site M2) & pyr 2 & 1.13 & - & 2.08 & - & 0.18 & 20.1 \\
\hline & troilite & $\operatorname{tr}$ & 0.75 & 30.6 & 1.02 & 60.7 & 0.15 & 9.7 \\
\hline & metallic phase 1 & met 1 & 0.01 & 33.5 & 0.00 & - & 0.23 & 6.5 \\
\hline & metallic phase 2 & met 2 & 0.01 & 29.0 & 0.45 & - & 0.17 & 1.8 \\
\hline & $\mathrm{Fe}^{3+}$ & $\mathrm{Fe}^{3+}$ & 0.44 & - & 0.59 & - & 0.24 & 8.7 \\
\hline Bjurböle (B) & olivine (site M1) & ol 1 & 1.15 & - & 3.14 & - & 0.13 & 16.2 \\
\hline \multirow[t]{6}{*}{ type L/LL4 } & olivine (site M2) & ol 2 & 1.15 & - & 2.86 & - & 0.17 & 37.5 \\
\hline & pyroxene (site M1) & pyr 1 & 1.16 & - & 2.46 & - & 0.17 & 9.4 \\
\hline & pyroxene (site M2) & pyr 2 & 1.15 & - & 2.05 & - & 0.16 & 18.5 \\
\hline & troilite & $\operatorname{tr}$ & 0.74 & 30.7 & 1.14 & 61.6 & 0.18 & 12.0 \\
\hline & metallic phase & met 1 & 0.02 & 32.3 & 0.23 & - & 0.13 & 1.7 \\
\hline & $\mathrm{Fe}^{3+}$ & $\mathrm{Fe}^{3+}$ & 0.45 & - & 0.48 & - & 0.30 & 4.7 \\
\hline Amber & olivine (site M1) & ol 1 & 1.16 & - & 3.23 & - & 0.15 & 10.4 \\
\hline \multirow[t]{10}{*}{ type L6 } & olivine (site M2) & ol 2 & 1.14 & - & 2.97 & - & 0.14 & 17.1 \\
\hline & pyroxene (site M1) & pyr 1 & 1.15 & - & 2.66 & - & 0.14 & 11.7 \\
\hline & pyroxene (site M2) & pyr 2 & 1.15 & - & 2.10 & - & 0.23 & 22.1 \\
\hline & troilite & $\operatorname{tr}$ & 0.66 & 29.9 & 0.56 & 90.0 & 0.27 & 6.7 \\
\hline & metallic phase 1 & met 1 & 0.05 & 34.5 & -0.16 & - & 0.19 & 8.1 \\
\hline & metallic phase 2 & met 2 & 0.08 & 34.2 & 0.22 & - & 0.15 & 5.4 \\
\hline & metallic phase 3 & met 3 & 0.43 & 28.8 & 1.75 & - & 0.49 & 2.1 \\
\hline & $\mathrm{Fe}^{3+}$ & $\mathrm{Fe}^{3+}$ & 0.37 & - & 0.80 & - & 0.28 & 9.5 \\
\hline & magnetite 1 & Magnetite 1 & 0.24 & 48.4 & 0.00 & & 0.30 & 4.0 \\
\hline & magnetite 2 & Magnetite 2 & 0.76 & 46.6 & 0.00 & & 0.29 & 3.0 \\
\hline Krasnoi-Ugol & olivine (site M1) & ol 1 & $1.16^{*}$ & - & 3.15 & - & 0.18 & 7.0 \\
\hline \multirow[t]{8}{*}{ type L6 } & olivine (site M2) & ol 2 & $1.16^{*}$ & - & 2.96 & - & 0.15 & 23.4 \\
\hline & pyroxene (site M1) & pyr 1 & 1.17 & - & 2.63 & - & 0.14 & 8.8 \\
\hline & pyroxene (site M2) & pyr 2 & 1.14 & - & 2.10 & - & 0.16 & 13.6 \\
\hline & troilite & $\operatorname{tr}$ & 0.75 & 30.8 & 0.89 & 61.0 & 0.16 & 11.5 \\
\hline & metallic phase 1 & met 1 & -0.02 & 34.3 & 0.02 & - & 0.14 & 6.3 \\
\hline & metallic phase 2 & met 2 & 0.02 & 33.2 & -0.02 & - & 0.20 & 20.0 \\
\hline & metallic phase 3 & met 3 & 0.11 & 20.2 & 0.02 & - & 0.12 & 3.0 \\
\hline & $\mathrm{Fe}^{3+}$ & $\mathrm{Fe}^{3+}$ & 0.52 & - & 0.61 & - & 0.31 & 6.4 \\
\hline
\end{tabular}

IS - isomer shift; B - internal magnetic field; QS - quadrupole interaction parameter, $\Theta$ - angle between direction of the magnetic field and the main axis of the electric field gradient; $w$ - HWHM (half width at half maximum); A - \% of spectral area. Experimental uncertainties for cited parameters are the following: for IS - $0.01 \mathrm{~mm} \mathrm{~s}^{-1}$; for QS - $0.02 \mathrm{~mm} \mathrm{~s}^{-1}$; for B - $0.2 \mathrm{~T}$; for w - $0.01 \mathrm{~mm} \mathrm{~s}^{-1}$; for A (\% of spectral area): for doublet $-0.5 \%$ and for sextets $-1.0 \%$. 
Table 2 Spectral areas of (olivine (ol), pyroxene (pyr), metallic phase (met) and troilite (tr)) of the tested samples with the determined level of similarity and Mahalanobis distance

\begin{tabular}{|c|c|c|c|c|c|c|c|c|c|c|c|}
\hline \multirow[t]{2}{*}{ Ordinary Chondrite } & \multirow[t]{2}{*}{ type } & \multicolumn{4}{|c|}{ Mineral phase } & \multicolumn{3}{|c|}{ Mahalanobis distance } & \multicolumn{3}{|c|}{$\begin{array}{l}\text { The level of similar- } \\
\text { ity } \%\end{array}$} \\
\hline & & ol & pyr & met & $\operatorname{tr}$ & $\mathrm{H}$ & $\mathrm{L}$ & LL & $\mathrm{H}$ & $\mathrm{L}$ & LL \\
\hline Baszkówka B1 & L5 & 33 & 16 & 23 & 25 & 4.4 & 5.7 & 14.5 & 15.2 & 1.8 & 0.0 \\
\hline Baszkówka B2 & L5 & 35 & 21 & 14 & 28 & 4.9 & 5.3 & 9.6 & 11.0 & 2.6 & 0.0 \\
\hline Baszkówka B3 & L5 & 28 & 24 & 13 & 33 & 7.4 & 7.6 & 10.6 & 1.6 & 0.2 & 0.0 \\
\hline Baszkówka B4 & L5 & 26 & 18 & 29 & 26 & 5.7 & 9.0 & 18.7 & 6.2 & 0.0 & 0.0 \\
\hline Mbale W & $\mathrm{L} 5 / 6$ & 39 & 19 & 23 & 15 & 1.5 & 4.6 & 14.3 & 62.4 & 5.5 & 0.0 \\
\hline Mbale E & $\mathrm{L} 5 / 6$ & 52 & 23 & 6 & 15 & 3.6 & 1.5 & 3.2 & 24.5 & 52.8 & 14.9 \\
\hline Mbale K & $\mathrm{L} 5 / 6$ & 53 & 23 & 0 & 18 & 4.4 & 4.2 & 3.8 & 14.9 & 7.8 & 8.2 \\
\hline Amber & L6 & 28 & 34 & 16 & 7 & 7.9 & 11.0 & 11.2 & 1.0 & 0.0 & 0.0 \\
\hline Bjurböle (A) & L/LL4 & 46 & 28 & 8 & 10 & 4.8 & 5.2 & 5.0 & 11.4 & 2.9 & 2.2 \\
\hline Bjurböle (B) & L/LL4 & 54 & 28 & 2 & 12 & 4.5 & 3.2 & 2.2 & 13.9 & 17.6 & 31.6 \\
\hline Krasnoi-Ugol & L6 & 30 & 22 & 29 & 12 & 2.5 & 7.2 & 17.8 & 42.0 & 6.2 & 0.0 \\
\hline Chelyabinsk No 1 & LL5 & 60 & 22 & 4 & 13 & 5.2 & 1.7 & 2.4 & 9.0 & 46.9 & 27.7 \\
\hline Chelyabinsk No 2 & LL5 & 56 & 15 & 7 & 19 & 5.1 & 3.7 & 4.7 & 9.9 & 11.7 & 3.4 \\
\hline Chelyabinsk No 3 & LL5 & 51 & 15 & 9 & 22 & 4.5 & 3.4 & 5.9 & 14.5 & 14.9 & 0.7 \\
\hline Chelyabinsk No 4 & LL5 & 58 & 14 & 6 & 19 & 5.6 & 4.7 & 4.2 & 6.6 & 6.0 & 4.8 \\
\hline Chelyabinsk No 5 & LL5 & 56 & 17 & 8 & 15 & 5.0 & 3.2 & 4.8 & 10.3 & 18.6 & 2.8 \\
\hline
\end{tabular}

- in Kanpur. There were differences in the concentration of iron in the main mineral phases (olivine, pyroxene, troilite and metallic phases). The largest differences were obtained for olivine and metallic phases.

The discrepancies in the results of percentages of spectral areas that the 3 Mössbauer groups received for the Mbale meteorite, are most easily explained by the fact that the laboratories in Warsaw and Kanpur received very non-representative samples for measurements. It is very unlikely that this meteorite would have such a highly inhomogeneous distribution of the four main mineral phases. Perhaps both samples were taken from meteorite fragment that were too small (much smaller than $1 \mathrm{~g}$ ).

\subsection{Meteorites from the "AB" collection (Bjurböle (a), Amber, Krasnoi-Ugol) and Bjurböle (B)}

From the meteorite collection, which we decided to call "AB", we got 3 powdered meteorite samples: Bjurböle (A), Amber, Krasnoi-Ugol. For one of these meteorites - Bjurböle (A), measurements on another sample - Bjurböle (B) - were performed. The second sample - Bjurböle (B) - was delivered to the laboratory in an unprepared form and powdered and measured in our laboratory.

The results of the analysis of the Mössbauer spectrum of sample Bjurböle (A) from the $\mathrm{AB}$ collection and sample Bjurböle (B) from our collection are shown in Fig. 2. A comparison of the percentages of spectral areas obtained for the sample Bjurböle (A) and Bjurböle (B) shows very large differences that cannot be explained by the sample preparation 
Table 3 Spectral areas of (olivine (ol), pyroxene (pyr), metallic phase (met) and troilite (tr)) of the samples of Chelyabinsk meteorite (Chelyabinsk E, Chelyabinsk W1 and Chelyabinsk W2) with the determined Mahalanobis distance and level of similarity

\begin{tabular}{|c|c|c|c|c|c|c|c|c|c|c|c|}
\hline \multirow[t]{2}{*}{ Ordinary Chondrite } & \multirow[t]{2}{*}{ type } & \multicolumn{4}{|c|}{ Mineral phase } & \multicolumn{3}{|c|}{$\begin{array}{l}\text { Mahalanobis } \\
\text { distance }\end{array}$} & \multicolumn{3}{|c|}{$\begin{array}{l}\text { The level of similar- } \\
\text { ity } \%\end{array}$} \\
\hline & & ol & pyr & met & $\operatorname{tr}$ & $\mathrm{H}$ & $\mathrm{L}$ & LL & $\mathrm{H}$ & $\mathrm{L}$ & LL \\
\hline Chelyabinsk E & LL5 & 57.5 & 28.0 & 1.7 & 12.7 & 4.4 & 2.7 & 2.3 & 15.1 & 25.0 & 29.8 \\
\hline Chelyabinsk W1 & LL5 & 61.0 & 24.0 & 1.0 & 11.0 & 6.0 & 3.2 & 0.5 & 5.2 & 17.1 & 81.6 \\
\hline Chelyabinsk W2 & LL5 & 58.9 & 29.2 & 2.2 & 8.5 & 5.8 & 3.3 & 1.8 & 5.8 & 17.2 & 42.5 \\
\hline
\end{tabular}

method. The Bjurböle (B) sample has (according to the $4 \mathrm{M}$ Method classification) the highest level of similarity to the LL type. Sample (A) has very low levels of similarity to any of the H, L, and LL types. This may indicate that sample Bjurböle (A) has been contaminated with a different material. We found the meteorite samples from the "AB" collection to be unreliable. This is also the explanation for the results obtained on the basis of measurements of the Amber and Krasnoi-Ugol meteorite samples.

It can be concluded, with a certain degree of probability, that the untreated sample is "typical" for the Bjurböle meteorite and represents the entire meteorite well. Comparison of Mössbauer results Bjurböle (A) and Bjurböle (B) are given in Fig. 1c and Fig. 1d.

\subsection{Chelyabinsk meteorite}

Sometimes intentionally non-representative, specific meteorite fragments are examined. An example are Mössbauer spectra of Chelyabinsk meteorite published by the Ekaterinburg group in 2017 [9]. In this case, specific fragments of the meteorite were intentionally selected for research. Samples No 1, No 2 and No 5 are fragments with light lithology, No 3 is fragment with mixed light and dark lithology and No 4 is fragment with black lithology. The different lithology of the analysed fragments is reflected in the results of the 4M method. Each of these measurements are correct, but the selection of a specific meteorite fragment makes it impossible to conclude the type of the entire meteorite.

In Table 3 the results of Mössbauer measurements of one Chelyabinsk sample published by the Ekaterinburg group in 2014 [16] (Chelyabinsk E) and the results of Mössbauer measurements of two Chelyabinsk samples published by the Warsaw group in 2014 [3] (Chelyabinsk W1) and in 2019 [7] (Chelyabinsk W2) are shown.

The 4M method applied for Chelyabinsk E, Chelyabinsk W1 and Chelyabinsk W2 confirmed the result obtained on the basis of the traditional classification. The results of the percentage of spectra of the Chelyabinsk group of Ekaterinburg, published in 2017, are very different from the results published in 2014.

The results published by the Ekaterinburg group in 2017 [9] are very interesting from the point of view of the study of various lithologies present in Chelyabinsk, but they cannot, however, constitute a comparative basis for the classification of ordinary chondrites, which the Ekaterinburg group did in its works published in 2017 and $2019[9,17]$. 


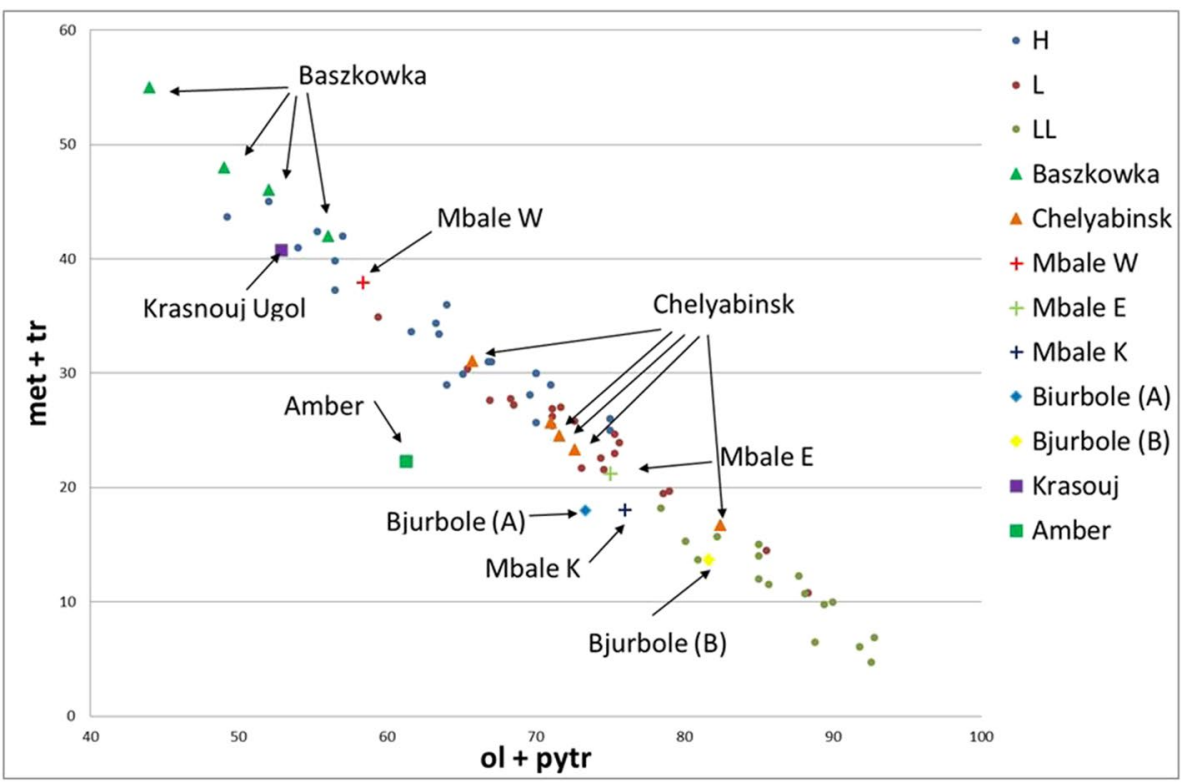

Fig. 3 Plot of the spectral areas of (metallic phases + troilite) vs spectral area of (olivine + pyroxene) for ordinary chondrites type H, L, LL and analysed samples

\subsection{D plots for representative and non-representative samples}

To analyse the reasons for the non-representativeness we decided to present following plots: spectral areas of metallic phase and troilite versus spectral area of olivine and pyroxene [(met + tr) vs (ol+pyr)], spectral areas of olivine and pyroxene and troilite versus spectral area of metallic phase $[(\mathrm{ol}+\mathrm{pyr}+\mathrm{tr})$ vs met $]$ and spectral areas of olivine and pyroxene and troilite versus spectral area of metallic phases $[(\mathrm{ol}+\mathrm{pyr}+\mathrm{met}) \mathrm{vs} \mathrm{tr}]$. These plots present unrepresentative samples compared to the representative samples from the database published in 2019 [7].

In Fig. 3, Three Chelyabinsk meteorite samples are outside of the region occupied by LL meteorites. The Baszkówka, Mbale W and Krasnoi-Ugol meteorite samples are outside of the region occupied by L-type meteorites. Such positions in the diagram suggest that there is an excess of the metallic phase or troilite in these samples.

In Fig. 4, Chelyabinsk meteorite samples and the Bjurböle (A) meteorite samples are outside of the region occupied by LL meteorites. The two Baszkówka, Mbale W and Mbale K, Krasnoi-Ugol and Amber meteorite samples are outside of the region occupied by L-type meteorites. Such positions in the diagram suggest that there is an excess of the metallic phase in these samples.

In Fig. 5, the Baszkówka meteorite samples are outside of the region occupied by L-type meteorites. It can be seen that these samples are outside the region occupied by any type of ordinary chondrites. This raises reasonable doubts to their representativeness. Such positions on the graph suggest that there is an excess of the troilite phase in these samples. 


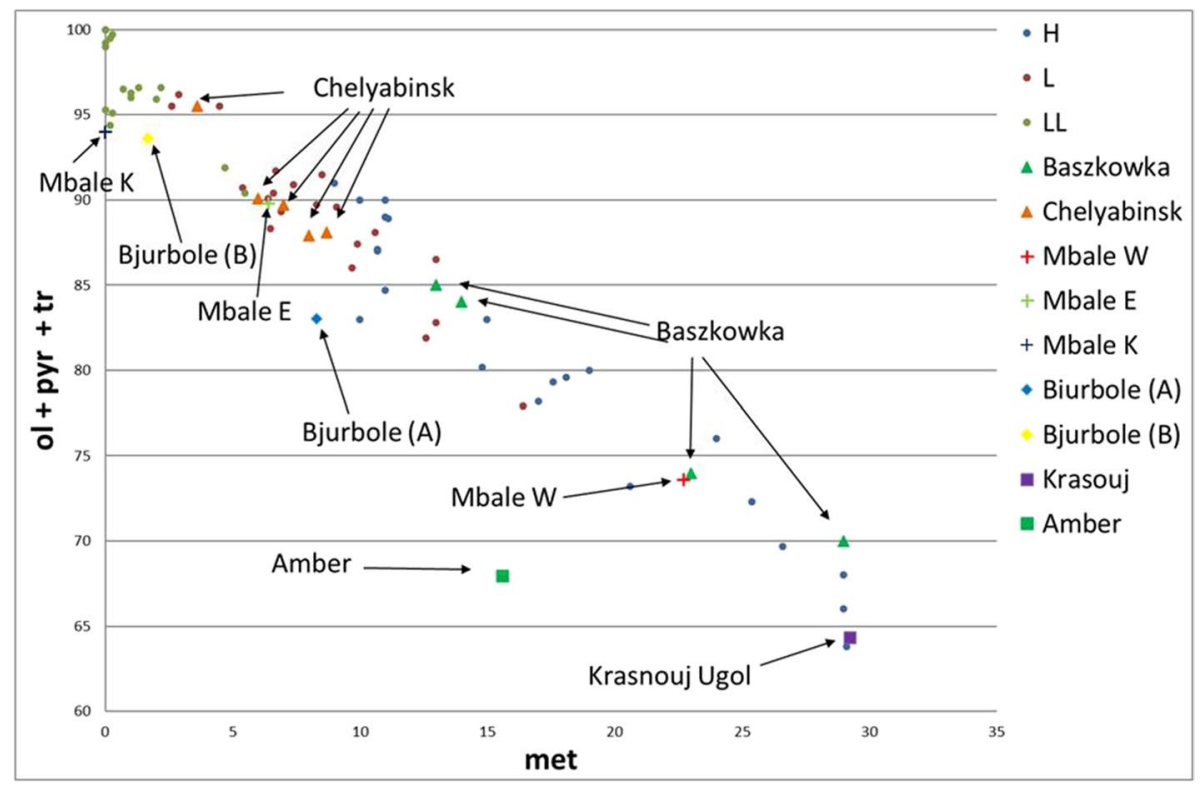

Fig. 4 Plot of the spectral areas of (olivine + pyroxene + troilite) vs spectral area of metallic phases for ordinary chondrites type H, L, LL and analysed samples

\section{Conclusions}

Based on the obtained results, we can assume that samples: Chelyabinsk No 1, Chelyabinsk No 2, Chelyabinsk No 3, Chelyabinsk No 4, Chelyabinsk No 5, Baszkówka B1, Baszkówka B2, Baszkówka B3, Baszkówka B4, Mbale W, Mbale K, KrasnoiUgol, Bjurböle (A) and Amber are not representatives for the whole meteorites. These samples cannot be a reference value in ordinary chondrite type classifications. In this paper, several methods of identifying such samples, using the Mössbauer spectroscopy and data analysis, were proposed. Our study shows how useful a tool, the $4 \mathrm{M}$ method can be, for distinguishing between representative and non-representative samples of ordinary chondrites.

To obtain a representative sample of ordinary chondrites for the Mössbauer research we need to:

- cooperate with a reliable source of samples

- ask for $1 \mathrm{~g}$ fragments from inside the meteorite and chosen without any specific intention

- the obtained fragment of the meteorite should be accepted by a specialist that excludes the presence of the fused crust

- the sample should be powdered under conditions preventing its oxidation and contamination

- literature data should be analysed in terms of the objectivity of the selection of samples, which we include in the database. 


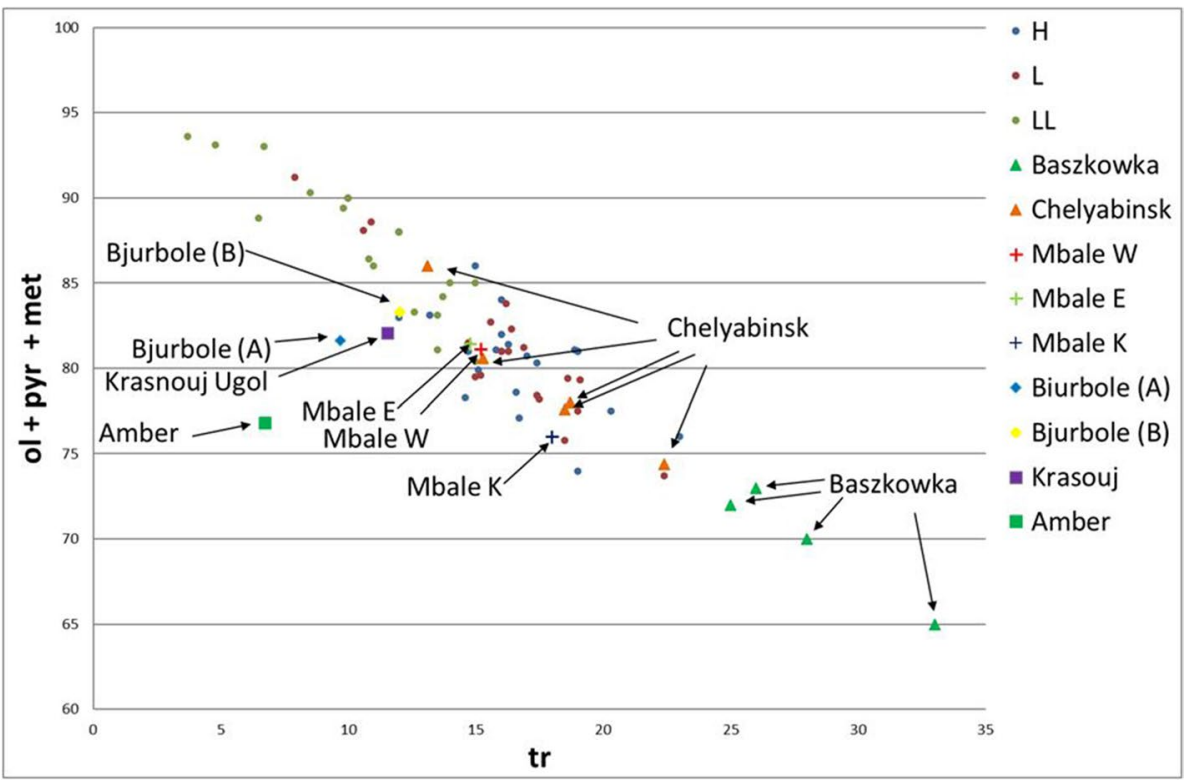

Fig. 5 Plot of the spectral areas of (olivine + pyroxene + metallic phases) vs spectral area of troilite for ordinary chondrites type H, L, LL and analysed samples

Acknowledgments We thank Marcin Cimała, Ansgar Greshake, Mike Gilmer, Tomasz Jakubowski, Kazimierz Mazurek, Jarosław Morys, Krzysztof Socha, Robert Verish, Łukasz Karwowski, and Jan Woreczko for generously supplying the samples of meteorites for our study.

Open Access This article is licensed under a Creative Commons Attribution 4.0 International License, which permits use, sharing, adaptation, distribution and reproduction in any medium or format, as long as you give appropriate credit to the original author(s) and the source, provide a link to the Creative Commons licence, and indicate if changes were made. The images or other third party material in this article are included in the article's Creative Commons licence, unless indicated otherwise in a credit line to the material. If material is not included in the article's Creative Commons licence and your intended use is not permitted by statutory regulation or exceeds the permitted use, you will need to obtain permission directly from the copyright holder. To view a copy of this licence, visit http://creativecommons.org/licenses/by/4.0/.

\section{References}

1. Herr, W., Skerra, B.: Mössbauer spectroscopy applied to the classification of stone meteorites. In: Millman, P.M. (ed.) Meteorite Research. Astrophysics and Space Series. Science Library, vol. 12, pp. 106-122. D. Reidel Pub. Co, Dordrecht (1969)

2. Gałązka-Friedman, J., Szlachta, K., Karwowski, Ł, Woźniak, M.: Mössbauer studies of Soltmany and Shisr 176 meteorites-comparison with other ordinary chondrites. Hyperfine Interact. 226, 593-600 (2014). https://doi.org/10.1007/s10751-013-0944-0

3. Szlachta, K., Woźniak, M., Gałązka-Friedman, J.: Porównawcze badania mössbauerowskie meteorytów: Sołtmany (L6), Chelyabinsk (LL5) i Grzempy (H5) (Mössbauer comparative studies of the Sołtmany (L6), Chelyabinsk (LL5) and Grzempach (H5) meteorites). Acta Societatis Metheoriticae Polonorum. 5, 115-120 (2014)

4. Gałązka-Friedman, J., Woźniak, M., Duda, P., Rzepecka, P., Jakubowska, M., Karwowski, Ł: Mössbauer spectroscopy—a useful method for classification of meteorites? Hyperfine Interact. 238, 11 (2017). https://doi.org/10.1007/s10751-017-1439-1 
5. Duda, P., Rzepecka, P., Jakubowska, M., Woźniak, M., Karwowski, Ł., Gałązka-Friedman, J.: Badania mössbauerowskie siarczków żelaza w chondrytach zwyczajnych typu LL (Mössbauer studies of iron sulphides present in ordinary chondrites type LL). Acta Societatis Metheoriticae Polonorum. 8, 30-39 (2017)

6. Bogusz, P., Brzózka, K., Górka, B., Szumiata, T., Woźniak, M., Gałązka-Friedman, J.: Classification of meteorites - Mössbauer comparative studies of three ordinary chondrites measured in different conditions. Acta Phys. Pol. A 134(5), 1070-1075 (2018). https://doi.org/10.12693/APhysPolA.134.1070

7. Woźniak, M., Gałązka-Friedman, J., Duda, P., Jakubowska, M., Rzepecka, P., Karwowski, Ł: Application of Mössbauer spectroscopy, multidimensional discriminant analysis, and Mahalanobis distance for classification of equilibrated ordinary chondrites. Meteorit. Planet. Sci. 54(8), 1828-1839 (2019). https://doi.org/10.1111/maps.13314

8. Gałązka-Friedman, J., Woźniak, M., Bogusz, P., Jakubowska, M., Karwowski, Ł: Application of Mössbauer spectroscopy for classification of ordinary chondrites-different database and different methods. Hyperfine Interactions 241(1), 1-12 (2020). https://doi.org/10.1007/s10751-019-1661-0

9. Maksimova, A.A., Oshtrakh, M.I., Petrova, E.V., Grokhovsky, V.I., Semionkin, V.A.: Comparison of iron-bearing minerals in ordinary chondrites from H, L and LL groups using Mössbauer spectroscopy with a high velocity resolution. Spectrochim. Acta A Mol. Biomol. Spectrosc. 172, 65-76 (2017)

10. Lagarec K. and Rancourt D.G: Recoil: Mössbauer Spectral Analysis Software for Windows, Version 1.0. Ottawa, Canada: Department of Physics, University of Ottawa. (1998)

11. Elewa, N. N., Cobas, R., Cadogan, J. M.: ${ }^{57}$ Fe Mössbauer study of the chainpur meteorite. Hyperfine Interact 237, 107 (2016) https://doi.org/10.1007/s10751-016-1315-4

12. Duda, P., Kazulo, P., Setniewski, A., Bogusz, P., Woźniak, M.: Preliminary results of Mössbauer measurements of Pultusk meteorite performed at room temperature $(300 \mathrm{~K})$ and at temperature of liquid nitrogen (80K). Acta Soc. Met. Pol. 9, 48-53 (2018)

13. Gałązka-Friedman J., Bauminger E.R., Bakun-Czubarow N., Siemiątkowski J., Stępniewski M.: Distribution of iron among metallic, sulphide and silicate phases in the new Polish chondrite Baszkówka. Abstracts of Conference ISIAME'96, Johannesburg, 4-8 November 1996

14. Gałązka-Friedman, J., Bauminger, E.R., Nowik, I., Bakun-Czubarow, N., Stępniewski, M., Siemiątkowski, J.: Comparative Mössbauer studies of the Baszkówka ordinary chondrite and some other meteorites. Geological Quarterly. 45(3), 319-326 (2001)

15. Gałązka-Friedman, J., Szlachta, K.: Mössbauer studies of sołtmany meteorite- preliminary results. Meteorites. 2(1-2), 73-77 (2012)

16. Oshtrakh, M.I., Petrova, E.V., Grokhovsky, V.I., Semionkin, V.A.: Characterizationof a Chelyabinsk LL5 meteorite fragment using Mössbauer spectroscopy with ahigh velocity resolution. Hyperfine Interact. 226, 559-564 (2014)

17. Oshtrakh, M.I., Maksimova, A.A., Chukin, A.V., Petrova, E.V., Jenniskens, P., Kuzmann, E., Grokhovsky, V.I., Homonnay, Z., Semionkin, V.A.: Variability of Chelyabinsk meteoroid stones studied by Mössbauer spectroscopy and X-ray diffraction. Spectrochim. Acta A Mol. Biomol. Spectrosc. 219, 206-224 (2019)

Publisher's note Springer Nature remains neutral with regard to jurisdictional claims in published maps and institutional affiliations. 